\title{
Corporate Social Responsibility Practices, Involvement and Participation of Major Tractor Farm Industries in India - A R eview
}

\author{
Effulgence \\ Vol. 16 (Special Issue) \\ January - June, 2018 \\ Rukmini Devi Institute of Advanced Studies \\ E-mail : effulgence@rdias.ac.in, Website : www.rdias.ac.in \\ $\mathrm{http}: / /$ effulgence.rdias.ac.in/user/default.aspx \\ M s. Saloni C haudhary ${ }^{1}$ \\ https://dx.doi.org/10.33601/effulgence.rdias/v16/iSpl1/2018/article0.14 \\ Dr. Rudra R ameshwar ${ }^{2}$ \\ M s. Raiswa Saha ${ }^{3}$ \\ Dr. Raghavendra G. R ao ${ }^{4}$
}

1, 2, 3 \& 4 - SRM U niversity, Sonepat (Haryana) India, " Thapar U niversity, Patiala (Punjab) India

\begin{abstract}
Corporate social responsibility (CSR) gained its popularity and attention in India since last decade. Business houses take more attention towards CSR activities due to more pressure from society's front. In India, many firms have taken initiatives in CSR practices to explore the problems of society. India is a land of agriculture; $80 \%$ people in India depend solely upon agricultural sector. To fulfil the requirements of agricultural farming, such people have a tendency towards green revolution. Hence, tractor farm industries have shown a rapid growth in taking cohesive participation in CSR supported by Indian law in serving the society at large.
\end{abstract}

In present research paper, three major farm companies have been dyed using case study approach - popularly known as Mahindra and Mahindra, New Holland and John Deere who are actively involved and participating in CSR activities. It has been found out that these companies believe in working on long-term business strategy with sustainable development approach by making well-structured plan on CSR .

Keywords: Stakeholder, Social responsibility, Economic Development, Environment, NG Os

\section{INTRODUCTION}

In modern times, Corporate Social Responsibility (CSR) is simply a term which is considered as a Corporate Initiative to levy and get accountability for the company's belongings on the surroundings and influence on social welfare (www.finances.bih.nic.in).
Another definition of CSR defines as "the responsibility of enterprises for their impacts on society" (www.ec.europa.eu). CSR mainly restrain the community development with various projects (educational, research and cultural) to improve the status of below poverty line people. CSR is not only responsible for social development, but, equally 
works in collaboration with social, environmental and economic agendas. CSR works for communities to become more advanced in terms of competitiveness at a global level.

CSR has not only taken decision in social level but, created an amalgamation of Social responsibility, Economic development and Environmental responsibility in a holistic fashion. CSR is a concept of charitable giving, which had been existing in India since early era of civilization. Post independence government sectors' have played an important role in CSR activity as well as non-governmental sector have also showed their interests in CSR activity. Now a day's, CSR discipline are involved in business strategies and decision-making in corporate sectors.

The development of communities is a more spectacular tendency in India in addition towards development of businesses for increasing humanitarian values, for the support of CSR large number of companies take part and spent some profitable amount of their annual turnover in CSR activities, the description of these activities in some space of their website, annual report, sustainable report and CSR report (www.pwc.in). Corporate work with a wind range of new issues (like cultural activities and regulating differences, adult and child labour standards, grafting and corruption, health crises in below poverty line people, human rights, deforestation, etc).

For the long-term growth of the companies, sustainable development principles are being adopted which is basically to safeguard the future without hampering the present growth. With Sustainable development, plans and principles at the forefront companies normally seek for more economic growth, social progress and environmental stewardship. After the amendment of company's law each and every SME's, working on CSR activities have to document and report their activities and publish it in the form of annual reports or CSR reports. In India out of top 500 companies, only 271 companies have structured plan and approach for CSR activities.

India has an incomparable growth rate in agricultural production, which has helped to decrease the rate of hungriness. The technology backed up by "Green Revolution" has increased the industrial growth rate as well as positive policy support to farmers. "H unger is the argument that is driving India to the spinning wheel" Quote authored by Hon'ble M ahatma Gandhi, India.

A new era of technology has replaced the old traditional culture in agriculture for fulfilling the need of India villagers. New machineries with technological up gradations works on small, medium, and large level for the development of new agricultural equipments which can be further used in agricultural and dairy farm (Singh, 2005).

A griculture is the backbone of India. However, general agriculture plays a very crucial role in Indian economy. In farm mechanization, productivity and greater out-put are two key offerings or contributions in any country for their development.

In Indian economy, agriculture accounts for $25 \%$ of GDP growth. In India 2/3, livelihood workforces are engaged in agricultural sector where, nearly $62 \%$ are employed of the entire population. After Green revolution in 1960, high yield verity of seeds, higher 
fertilizers and higher mechanization systems were adopted to give higher returns.

Agricultural equipment technology in India was highly influenced by farm development technology patterns of England. Tractors are a big achievement in farm machinery technology; it plays a crucial role in agriculture ( $M$ andal et al., 2008). Since the beginning of tractor, the demand of tractor increased per five decades in manufacturing units, as we see the record of tractor production as 3 lakhs per year (J ain, 2006).

In agricultural land, reclamation and carrying out various type of cultivation of crops with attached agricultural equipment and other hand tractor are used in commercial purpose, handling operation in industries. Farm mechanization in India is increased as the source of mechanical power for the increased rate of higher productivity in crop land.

As we see in international figures or records, India has bagged $8^{\text {th }}$ position in consuming tractor, for globally it is about 3\% in agriculture machinery. A fter USA and Russia, India is in third position in agricultural production, which has made the country more powerful in economic supremacy ( $M$ andel et al., 2008). India has carried out about $20 \%$ production of tractors in global presence. The major demanding state for tractor usage are Punjab, Haryana and Uttar Pradesh having alluvial soil, due to the nature of soil no more deep tillage required during before crop growing period and after harvesting period. That is why in this region 30-40 hp tractors are more demandable.

\section{MAHINDRA TRACTOR INDUSTRIES}

With the advent of industrial revolution the development of more complicated agricultural machineries, agricultural farming methods took place with a huge momentum.

$M$ ahindra Company for example is producing tillage implements, tractors, irrigation pumps and baler etc.

1. Mahindra tractors have come up as an international brand namely by Mahindra \& M ahindra.

2. In 1945, M ahindra group was set up with US $\$ 3$ billion in Indian market to make utility vehicles for daily use as a brand name of Mahindra \& Mahindra Limited. By the production plant set up in India, India distribute tractors in tractor demanding countries like Russia, Europe, Asia, USA, South A merica etc., M ahindra brand at that time number one producer in tractor market in world. It sold out about 85,000 units annually.

3. In 1983, Indian market show rapid sales in tractors, in this sale $M$ ahindra takes number position to sale maximum tractor in world. In two Indian state $M$ ahindra tractors sale in different name in Gujarat beneath the label $M$ ahindra Gujarat and in Punjab it sale under the label Swaraj.

4. Mahindra obtain all the tractors in Gujaratby-Gujarat government in 1999 and in 2004, $M$ ahindra purchase $64.6 \%$ stake in Swaraj.

Mahindra \& Mahindra sales more than 11 lakhs tractor in worldwide under farm equipment division, its growth is the $5^{\text {th }}$ largest in agricultural equipment manufacturing sector at international market.

CSR is a concept where by companies take part in 
social activities to contribute to preferential living standard of society and pollution free environment. Organization takes part in social activities by recognizing their behavioural impact on their employees, customers, nearby communities and their stakeholders. Organization shows their involvement in social activities by reconceptualising their norms. Corporate social responsibility is defined as 'Society expected from the voluntaries of business do their work under the line of legal law decided by Indian government, ethical beneficial for people living in society, commercial and public level' (Pawar 2015). Corporate social responsibility is an important strategy for the companies to survive in cut-throat market environment.

\section{C orporate Social R esponsibility at M ahindra \& M ahindra Limited}

For the development of nation economic, social, and environmental development in sustainable manner, all three are progress in one slide not back to back. According to $M$ ahindra, corporate CSR is not about wealth, its involucres the responsibility at durable time and the responsibilities changes by the requirement of time-to-time.

There are total 16 members in this committee, which comprises of senior executive nominated by the management. Company has its separate CSR department, which is accountable for-

1. CSR council designed plan follow by Mahindra Corporate

2. Mahindra works with adequate planning and these planning implements in proper time and evaluates their planning if any need to full fill the CSR enterprise

3. Reporting the impact of CSR initiatives of the company

4. Building strategic partnership with government, non-government organizations and other corporate for CSR of the company

5. Suggesting and facilitating way for employees 'participation in CSR

\section{Mahindra \& M ahindra CSR Investment}

CSR Investment of $M$ ahindra $\& M$ ahindra $L$ td. in the financial year 2013-2014 is as under: Total CSR Investment is 1,211.45 M illion and shown below in Table 1 in detail.

Table 1. Showing Investment in C SR by M ahindra \& M ahindra

\begin{tabular}{|c|c|}
\hline Type of C SR Initiative & Rs. (in M illions) \\
\hline Education & 611.73 \\
\hline Health & 30.91 \\
\hline Sport & 330.89 \\
\hline Culture & 78.89 \\
\hline Other & 135.46 \\
\hline Environment & 23.56 \\
\hline
\end{tabular}

$M$ ahindra and $M$ ahindra believe that education is the most powerful hindrance for lection of lives. Education of human being not affects earning of but also develops self esteem of the human being and devel oped the standard of living.

\section{Mahindra \& Mahindra - Various Educational CSR Initiatives}

Project Nanhi Kali - Mr. A nand Mahindra started project $\mathrm{N}$ anhi Kali in the year 1996 with a belief that women empowerment through education will bring a 
positive charge in social level development in country, which is constitutive for developing strong nation girl education is very important for reduction the gap between sex ratio of boy and girl, maternal mortality, improvement in health and nutrition, social equality. Thought this project company is playing very important role in developing country's social equality and affluence through legislation quality education girls.

The Nanhi kali project was start with the help of K.C M ahindra Education Trust and now is jointly manage with the help of Naandi Foundation. This foundation conducted program joining with government and nongovernment school before and after school homes. Where minor communities girl are taken planned structure and academic program that help them in providing necessary things like school uniform, books, notebook, shoes, school bag and taught basic subject like Mathematics, Science, English and other language for girl students. Mahindra provides its owntrained teachers who come from the community itself, which ensures greater efficiency of the project $\mathrm{Nanhi}$ Kali.

In this program, each girl is sponsored by the individuals or corporate and they receive the regular progress of that particular girl in education. The amount required for sponsorship of each girl from $1^{\text {st }}$ standard to $5^{\text {th }}$ standard is only Rs: $3000 /-$ and Rs: 4,200/- for girls from 6th to 10th standard. This project has spread all over the country and even across the country providing education to more than $1,00,000$ girls. Most of the centers are working in rural and tribal areas, where education is very difficult to provide ( $M$ ahindra $\& M$ ahindra $L t d$.) $M$ ahindra is supporting with full motivation and still working on school as well as college level. Mahindra has started the college, which provides hire education to student started in the year 1997.

Mahindra provide Education relating to foreign language and basic studies as well as provide critical thinking to face the challenges of the life positively. $M$ ahindra \& M ahindra has started pride school for youth form socially and economically backward communities to improve their life standard. $M$ ahindra has started five school in different cities like Pune, Chennai, Chandigarh, Srinagar and Patna. M ore than 9,300 students have learnt the livelihood skills in these schools. Mahindra provide to students $100 \%$ Placement (Pawar, 2015)

\section{Mahindra \& Mahindra Limited - Environment Initiatives}

$M$ ahindra is straight-out to philanthropies the environment. Its eco- friendly activities shows responsible behavior of $M$ ahindra towards environment. $M$ ahindra has its zero wastewater from its plant. $M$ ahindra had systematically used old terms transforming into new practices for long-term sustainability. The biggest project initiated of $M$ ahindra is Mahindra Hariyali for environment protection. Mahindra was set up a project in 2007 with goal to planting $10,00,000$ trees to increases the natural beauty and decreases the green house effect.

After $M$ ahindra in tractor industries, the leading company is New Holland, which takes initiative in corporate social responsibility as well as in environment. 


\section{New Holland in Agriculture Industrial Sector}

New Holland founded in Pennsylvania by $A$ be Zimmermann in 1895, and making first tractor in 1918 for agriculture used. New Holland comes forwards in the form of global brand in agriculture produced by $\mathrm{CNH}$ Industries. New Holland has 18 plants spread globally 6 joint venture in A merica's, A sia and Middle East, the corporation is present 170 countries and the main headquarter are Turin, Italy.

Exceptionally, they provide best quality to their delight customer by delivering best in class products and services by working together with their dealer and suppliers. For the farmer easiness, New Holland makes NH Drive tractor work on use of the advanced PLM (Precision Land M anagement) technology for precision farming (www.auroracoop.com).

New Holland company apply a new advance techniques in there tractor open-connect-smart it's a supportive techniques for farmers to detect the location of their tractor (www.agriculturel.newholland.com). In addition, farmer determines the fuel level in their tractor in $\mathrm{NH}$ drive tractor. In India $\mathrm{CNH}$, the world largest company in manufacturing unit of agricultural equipments is providing their best source and resources (www. thehindubisnessline.com).

New Holland works for sustainable growth with environmental, economic and society for future generation. New Holland agriculture providing support for local communities' farmer preservation of natural resources (www.agriculture1.newholland.com). Company makes commitments day to day recognized to complete it in sustainability manner. Company sustainability targets made by public through sustainable plan and sustainable reports; define every yearly performance report and social economic changes.

Whereas, Sustainability Development Goals (SDGs) scenario analysis by UN and adopted by 193 UN M ember state in 2015. SDGs defined agenda works on set their goals and targets for 2030 , mainly supremacy and aspiration for the development at global level (CNH sustainability report, 2015). In 2006 new theories analysis by the company and interpreted its results, focus on identified the material aspect and define new target to be in sustainability plan.

$\mathrm{CNH}$ agriculture industries committed to protect environment and do favorable CSR activities for people to their social development by making sustainable plan year vise as the need of people $(\mathrm{CNH}$ sustainability report, 2015).

\section{New Holland - CSR Activities}

In globally world, India is one of the strongest markets and grows rapidly ahead. For the sustainability growth, India not works only on economic but also takes concept of CSR. It is accepted by globally, if the country governance needs long-term business stability it would be work on social, environmental and ethical responsibilities ${ }^{20}$. New Holland Fiat (India) Private Limited (herein after known as "NHFIPL") too shares a similar CSR / Sustainability focus.

They are committed to maintain highest standard of occupational Health \& Safety to prevent ill health and protect their employees and those working on their behalf from any potential injury. Their goal is to provide a clean, healthy and safe work environmental through continual improvement, awareness and training. They shall achieve this by responding 
appropriately to recognize, control or eliminate potential safety \& health hazard and ensuring compliances of applicable legal and other requirements.

New Holland common features on CSR:

- $\mathrm{CNH}$ industries globally work with anti corruption by taking record of each region

- Corporate and sustainable governance: Industries follow the rules according to government

- Maintain a continuously update risk management system

- Company capable to operate climate change, earthquakes, and other environmental factor

- Respect human and labour right

- Promotion of work environmental drive by training course for using multiple tools

- For promotion equal opportunities for performance and leadership

- To done commitments, population affected by natural disasters

- A rea effected by natural disaster support to their people with financial and social level

- Promoting sport profession of young people

- Promoting road safety behaviors

- To maintain relationship with public and private

- Try to finish hunger and poverty

- Promote the value of education

- To create awareness in to people about gender equality and women empowerment

- By running health, camp tries to reduce health illness of people

- Insure for protect environment
- Provide training programs to employees to improve vocational skills

- Develop some project for improvements of social business

- Try to develop sustainable framework for slum area at social level

\section{Sustainable growth in CSR New Holland runs some projects working needy area to maintain the status of undeveloped area.}

Primary E ducation (Mission Education Project)

New Holland Agriculture aims to promote and catalyze universal education among underprivileged children in rural/ semi urban area, create process to embrace these children into main stream in sustained manner, strength and their abilities to cope up with formal education system, move them to emerge in a direction help to create nation development (www.newholland.com).

With this objective, the Mission Education (ME) projects have been operationalised from $1^{\text {st }} \mathrm{J}$ an 2016 with $\mathrm{Nai}$ Disha free education society in Sector 29, Noida in partnership with SMILE Foundation. The center is non-formal center organized education activities on the curriculum of the National Institute of Open Schooling (NIOS). The project is hold on education of 200 children in age 4 to 14 years covering a total 94 female and 104 male.

In academic grading ranging from class I to III, the center is organize six days a week (Monday to Saturday) planed classroom and timing are $8 \mathrm{am}$ to $1.30 \mathrm{pm}$ from class II to III and $1 \mathrm{pm}$ to $5.30 \mathrm{pm}$ for class I.

Medical Ambulance Project: 
Primary healthcare is one of the almost required for everyone. Still, there is a lack to provide primary healthcare facilities to rural area in India or it may be expensive.

To compete the need of these needy segment $\mathrm{New}$ Holland provide mobile ambulance services, which provide healthcare facilities to rural area and villages masses and their doorstep nearby the grater $\mathrm{N}$ oida.

\section{New H olland E nvironmental Protection Policy}

- New Holland is committed to protect our environmental by continually improving our processes and products. They will prevent pollution and ensure compliance to applicable legal and other requirements, strive for efficient use and conservation of all natural resources and continuously improve on our environmental performance indicators

- The plant in Noida (India) water conservation done by recycling daily 72,000 liters water released by manufacturing unit and domestic area (mainly focusing on the paint shop and on all lavatories).

- Shortage of fossil fuel and to seen the air pollution produced by automobiles major problem in all over the world due to this so, many factor are arises by this. $\mathrm{CNH}$ industry tries to make such type of engine working on renewable resources. Renewable resources replace the fossil fuel slowly and slowly. It's a cheap source of energy and pollution free.

- $\mathrm{CNH}$ industry working on cleans leader technology by using renewable resources as an energy source and makes environment pollution free.
- Wastage is major problem now a days, $\mathrm{CNH}$ industry in plant recycling the all the type of wastage. During manufacturing workers, separate the wastages with the help of bin. Solid, Liquid and Gases all three kind of wastage generate through manufacturing unit of industries some are toxic and some are non-toxic, but it is necessary to recycled all the bins.

- $\mathrm{CNH}$ industry work on Low carbon emission, global warming shows unpredictable results it increases day by day by releasing increasing the source of carbon.

- Soil productivity main over a time by using biomass for fuel and power required for healthy soil. Maintain the fertility of soil, prevent soil erosion, make essential nutrients in it all are biological attributes. For maintain the soil fertility to agriculture harvesting level should be maintain.

\section{Role of J ohn Deere in Agricultural Practices - $\mathrm{H}$ istory and Plans}

John Deere is American cooperation manufactures agricultural equipment. Company established in 1837. At earlier stage, they made only steel plough later on as time goes, industries made different type of implements. In 1918, it entered in tractor industries. J ohn Deere is celebrating $175^{\text {th }}$ anniversary. It works on three norms:

1. Protect the environment.

2. Provide safe work place.

3. Promote personal development. 
In year 2000, J ohn Deere had set up production unit in the form of business alliance and joint venture with Larsen \& Toubro Ltd. $(L \& T)$ in Sanaswadi, rural area near Pune District, M aharashtra. M oreover, it has popularly new name: ' $L \& T$ J ohn Deere Private $L t d$. ', and manufactured tractors under the $L \& T$ - John Deere name for sale in India, and under the John Deere name for worldwide sales.

Generally, they work on based integrity, quality, commitment and innovation with zero $\%$ accident. John Deere had leveraging the strengths and unique capabilities of three types of businesses:

i) Global Growth Businesses

ii) Complimentary Businesses

iii) Supporting Businesses
For completing the business strategy developing the capabilities for reaching goals:

i) Deep Customer U nderstanding

ii) Deliver Customer $V$ alue

iii) W orld- Class Distribution System

iv) Grow Extraordinary Global Talent

Global macro-trends present significant opportunities for J ohn Deere:

$\checkmark$ Universal population living and income growth

$\checkmark$ Universal infrastructure needs

$\checkmark$ Different line customer combine to form new fragments

$\checkmark$ Apply new techniques in technology

Fig.1. J ohn Deere planned for E co-system

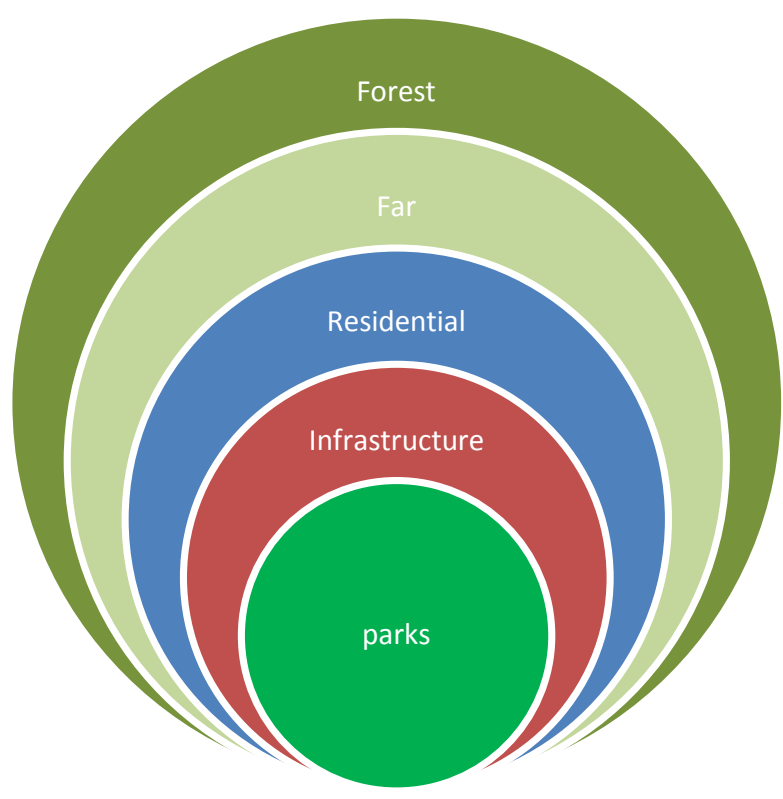

At their financial year, 2011 company works with nine millions hours for the making construction and forestry equipment without lost time accident with in a sustainable manner. 
J ohn Deere India Private (J DIPL) plans work on CSR to under as under taken and administer as per the provision of companies Act, 2013 and its Rule (www.johndeere.co.in). Refer Fig. 1. for details.

1. Solution of limiting hunger

2. Education play important role in every nation development.

3. JDIPL inspire to develop and retouch communities.

4. John Deere foundation provides facilities to people suffering from natural disaster, In India team operation for dental checkup for primary students nearby villages.

5. Other noticeable points by JDIPL

- Providing food to overcome hunger

- Water easily available to below poverty line people

- Organized camps for increase the awareness of people about health

- Provide hygiene and nutritional food

- Run scholarship scheme for SC, BC, ST and economical drive girls

- Free training programs to provide computer skills

- Providing funds to education center

- Providing funds to improve backward region schools

- Organized tanning program for improve learning skills for teachers (anganwadi) workers

- Help to educate the youth

- Providing common living facilities

- Organized tanning programs to increase their vocation skills for their employee

- Develop strong communities infrastructure
These are the various points, which are under taken in JDIPL projects. For completing these projects, they identified the tools to understand schedule VII of Rule.

Role of J ohn Deere in Environment: John Deere mainly works to reduce environmental impact, create product and solution help to customers conserve resources.

\section{Strategy of J ohn Deere to explore B usiness:}

Global micro trends present significance opportunities for john Deere

i. To increase the universal population living standard and increase the economic rise in growth rate

ii. To develop Universal new advance infrastructure for easily living

iii. To develop different line customer into same segment

iv. To develop advance technology for easy comfort of people

v. Serving to customer, employees and investors

\section{CONCLUSIONS}

Comparative Study of MAHINDRA \& MAHINDRA, New Holland and John Deere (based on various parameters as discussed above)

Area Covered by Sales:

Modestly studied most of the agricultural land covered by $\mathrm{M}$ ahindra \& $\mathrm{M}$ ahindra. New Holland and J ohn D eere together are showing futuristic sustainable 
approach in business to Mahindra due to major demand of $M$ ahindra tractors in the region of $U$ ttar Pradesh, M aharashtra, A ndhra Pradesh etc.
New Holland covered most the agriculture land in Gujarat and Madhya Pradesh. John Deere covered Tamil Nadu and M aharashtra.

Fig.2. Represent sales chart of $M \& M, N H$ and J D

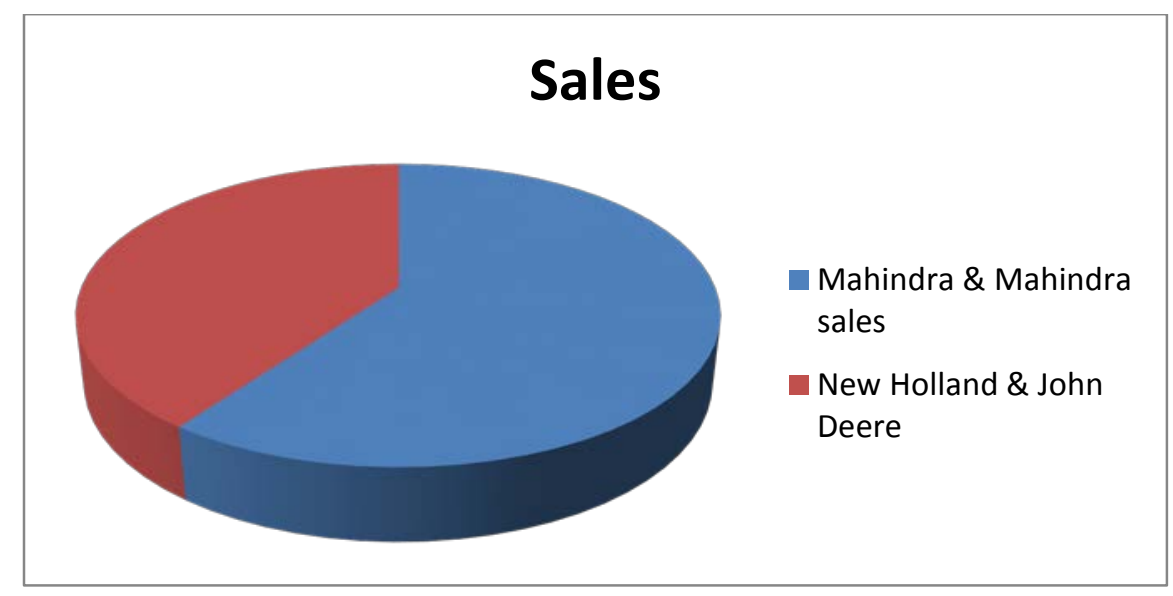

CSR Activity:

Study findings based on comprehensive conclusion drawn from active or ongoing CSR activities in India w.r.t. $M$ ahindra \& $M$ ahindra $L$ td. cover in largest area by performing various activities in routine manner like education for girl child, tree plantation and to improve the status of minor communities.

Fig.3. Represent C SR activity by M \& M, NH and J D

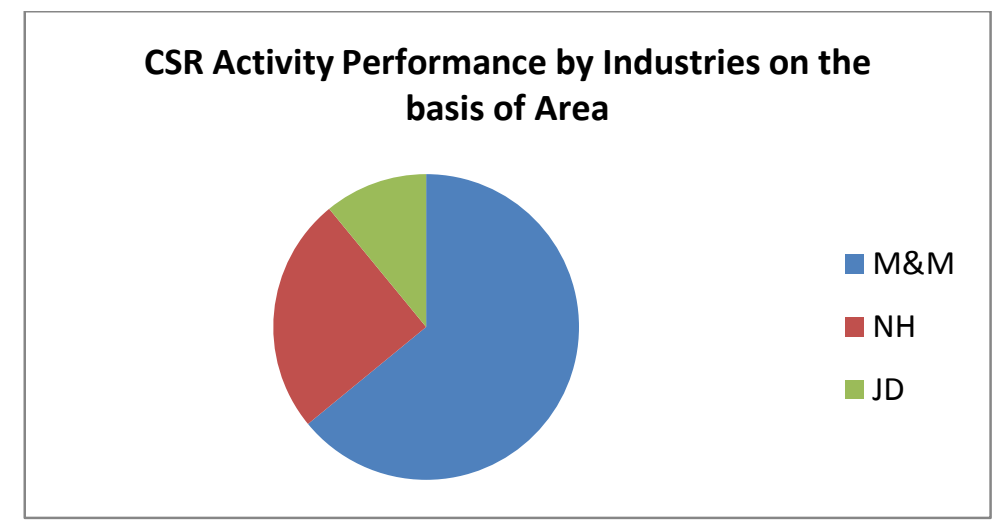

Secondly, another major industry New Holland performs CSR activities nearby area of their production plant. They joined with educational institute for providing the necessary survival facilities to rural area and the last third major industry is J ohn Deere. They collaborate with another group and 
perform CSR activities in India. They restrain their customer to use natural resources for protect environment.

\section{REFERENCES}

1. "Energy Efficient and Renewable Resources". US department of energy, EERE Information Center

2. "New Holland Agriculture Gold Sponsor of Sustainable Innovation Forum Alongside COP18" http://agriculturel.newholland.com ,N ov 29,2012. Accessed on March 23,2017. $5.42 \mathrm{am}$.

3. 1-877-EERE-INFO (1-877-337-3463), eere.energy.gov/informationcenter DOE/EE0400, July 2011.

4. CNH Sustainability Report 2015.

5. http:// agriculture1.newholland.com accessed on $M$ arch 22, 2017. 10.30.

6.

http:// ec.europa.eu/enterprise/policies/sustainab lebusiness/corporatesocial responsibility/index_en.htm.

7. http:// Finances.bih.nic.in/documents/csrpolicy.pdf accessed on Thursday, March16, 2017, 2.12:45.

8. http:// www.pwc.in, Hand book of corporate Social Responsibility in India.

9. http://www.thehindubusinessline.com accessed on $M$ arch22, 2017. 10.58.

10. J. Srikant (2017), “We expect double-digit growth this year in agricultural equipment segment: CNH Industrial", updated by june16, 2016. Online accessed on March 23, 2017 at 4:19 p.m.

11. Jain Ramesh C. (2006), "Tractor Industries in India-Present and future". Paper presented at roundtable forum for regional agricultural machinery manufacturers and distributors associations, Seoul, K orea, 22-23 N ovember.

12. Mandal Subrata Kr., Mainty A tanu (2013), "Current Trends of Indian Tractor Industry: A critical review", CSIR-Central Mechanical Engineering Research Institute, Durgapur, India. www.pscipub.com/A SR, E-ISSN: 2311-0139, 3(2), 2013:132-139.

13. Pawar M anesh Parmeshwar (2015), "Corporate Social Responsibility at $M$ ahindra \& $M$ ahindra Ltd.-A case study", IJSSR: Oct- Dec 2015 V ol.01 Issue (III).ISSN : 2454-3187.

14. Singh Sukhpal (2009), "A gricultural Machinery Industry in India: A Study of Growth, Market Structure, and Business Strategies" Centre for $M$ anagement in agriculture (CMA), Indian Institute of $M$ anagement A hmadabad (IIMA), A hmadabad.

15. Singh, Gyanendra (2005). "A gricultural Machinery Industries in India ( $M$ anufacturing, marketing and mechanization promotion)", Director, Central Institute of Agricultural Engineering, Bhopal.

16. www.johndeere.com

17. www.mahindra.com/about-us/socialresponsibility

18. www.newhollandindia.co.in 